Patryk Gutierrez

Uniwersytet Wrocławski

Artur Ławniczak

Opiekun naukowy — Scientific Tutor

DOI: $10.19195 / 1733-5779.19 .9$

\title{
Władza wykonawcza w Portoryko i w Polsce - porównanie oraz analiza wybranych uregulowań konstytucyjnych
}

\section{JEL classification: K1}

Słowa kluczowe: Konstytucja Rzeczypospolitej Polski, Konstytucja Portoryko, władza wykonawcza, Gubernator Portorykański, Prezydent Rzeczypospolitej Polskiej

Keywords: Constitution of Poland, Constitution of Puerto Rico, The Executive Branch, President of Poland, The Governor of Puerto Rico

\begin{abstract}
Abstrakt: W artykule przedstawione oraz omówione zostały najważniejsze zagadnienia odnoszące się do modelu egzekutywy. Z tego względu uwzględnia się jedynie portorykańską władzę wykonawczą, która nie ma zastosowania na obszarze Stanów Zjednoczonych Ameryki, a z którą ono jest powiązane jako tzw. nieinkorporowane terytorium stowarzyszone. W pierwszej kolejności zostało zdefiniowane pojęcie władzy wykonawczej zgodnie z obowiązującą w literaturze prawniczej terminologią. Następnie przedstawiony został podział władzy, który istnieje w Portoryko i w Polsce. Dalej omówiona została egzekutywa, w szczególności pod kątem struktur oraz sposobu jej wykonywania. W artykule dokonano analizy prawno-porównawczej w odniesieniu do wyborów na Gubernatora portorykańskiego czy Prezydenta RP oraz długości ich kadencji. Ponadto analizie tej poddano takie zagadnienia, jak: uprawnienia oraz obowiązki czy zdarzenia losowe i inne okoliczności przewidziane w Konstytucji, które również dotyczą Gubernatora portorykańskiego oraz Prezydenta RP. Końcowe konkluzje zawarte $\mathrm{w}$ artykule naukowym podsumowują dokonaną uprzednio analizę prawno-porównawczą konstytucyjnych uregulowań egzekutywy. W szczególności wymienione zostały cztery zasadnicze różnice, które występują w Portoryko i w Polsce.
\end{abstract}




\title{
Executive power in Puerto Rico and in Poland - the comparison and analysis of some constitutional issues
}

\begin{abstract}
In the paper entitled Executive Power in Puerto Rico and in Poland - the comparison and analysis of some constitutional issues, I decided to compare two different constitutional regulations of executive power in Latin America and Europe (Puerto Rico and Poland). At first glance, the both countries are republic with the same division of power between: executive, legislation and judicial. But on the other hand, the main differences have been established in the provisions of the Constitution. So, for this reason I'm trying to look for the answer for next questions: who performs the executive authority and whether this power is shared or not and how long it lasts during the term of office (for example). Therefore, in my paper I showed the differences and similarities on this range: between Puerto Rican Governor (with the Council of Secretaries) and Polish President (with the Council of Ministers).
\end{abstract}

\section{Wstęp}

W niniejszym artykule skupię swoje rozważania wyłącznie na władzy wykonawczej portorykańskiej sensu stricto (według Konstytucji Portorykańskiej z 1952 roku, dalej: KP), porównując ją z przyjętym w Polsce modelem ustrojowym. $\mathrm{Z}$ drugiej jednak strony, ze względu na wzajemne relacje pomiędzy władzą wykonawczą i ustawodawczą oraz sądowniczą, ich powiązania zostaną przedstawiane jedynie w niezbędnym zakresie. Natomiast skoncentruję się w swych rozważaniach na porównaniu konstrukcyjnych uregulowań egzekutywy, które obowiązują w Portoryko oraz w Polsce. Dodatkowo należy również wspomnieć, że Portoryko jest terytorium zależnym Stanów Zjednoczonych Ameryki, czyli tzw. nieinkorporowanym terytorium stowarzyszonym. Ponadto, wspomniane rozważania zacznę od przedstawienia pojęcia władzy wykonawczej, które występuje w literaturze, a następnie przejdę do porównania oraz analizy uregulowań dotyczących egzekutywy (w obu zaproponowanych modelach ustrojowych).

\section{Pojęcie władzy wykonawczej}

Władza wykonawcza odgrywa fundamentalne znaczenie dla państwa oraz dla każdego społeczeństwa. Od samego początku funkcjonowania zbiorowości ludzkiej pełniła bardzo ważną rolę. Koncepcja sprawowania władzy wykonawczej przez wieki ewoluowała, przy czym sposób patrzenia na nią również ulegał zmianom. Obecnie na świecie każde państwo ma swój „własny system rządzenia”, tzn. odmienny sposób wykonywania na swoim terytorium władzy publicznej. W literaturze podkreśla się, że władza wykonawcza to „działalność polegająca na wykonywaniu zadań publicznych mających na celu realizację dobra ogólnego, interesu publicznego"l.

\footnotetext{
1 B. Banaszak, Prawo konstytucyjne, Warszawa 2012, s. 481.
} 


\section{Podział władzy w Portoryko i w Polsce}

W ustroju Portoryko występuje bardzo dobrze znany na gruncie państw europejskich (oraz również w Stanach Zjednoczonych Ameryki) tzw. Monteskiuszowski trójpodział władzy ${ }^{2}$. W konstytucyjnych uregulowaniach charakteryzuje się on tym, że władza ustawodawcza sprawowana jest przez Zgromadzenie Ustawodawcze (Izbę Reprezentantów oraz Senat), a władza sądownicza przez Sąd Najwyższy Portoryko oraz inne sądy, które zostały ustanowione odpowiednią ustawą (art. 5, pkt $1 \mathrm{KP}$ ). W tym miejscu dodać należy, że ze względu na rozbudowany i kilkuinstancyjny system sądownictwa na terytorium Portoryko, który jest dodatkowo powiązany z amerykańskim modelem sądowniczym tzn. Stanów Zjednoczonych Ameryki, to w moich rozważaniach te kwestie pozostawione będą na marginesie, a skupiać się będę wyłącznie na egzekutywie. W tym przedmiocie należy uściślić, że władza wykonawcza na obszarze Portoryko wykonywana jest przez tamtejszego Gubernatora (art. 4, pkt 1, KP), a obowiązujący tam republikański ustrój polityczny oraz występujący podział władzy - na ustawodawczy, sądowniczy, wykonawczy — zostały zagwarantowane na samym początku w Konstytucji Portorykańskiej (art. 1, pkt 2, $\mathrm{KP})$. Zagadnienie to również poruszone zostało w literaturze portorykańskiej przez Williama Vázquez'a Irizarry, który początkową treść postanowień wskazanych artykułów — od III do V — tamtejszej Konstytucji z 1952 r. przyporządkował oraz utożsamił z kolejno odpowiadającą im władzą ${ }^{3}$.

W Polsce, podobnie jak w Portoryko, również istnieje trójpodział władzy, który jednocześnie stanowi jedną z sześciu najważniejszych zasad konstytucyjnego ustroju państwa polskiego ${ }^{4}$. Zgodnie z artykułem 10 Konstytucji: „Ustrój Rzeczypospolitej Polskiej opiera się na podziale i równowadze władzy [...]" oraz dalej w tym samym artykule czytamy, że „Władzę ustawodawczą sprawują Sejm i Senat, władzę wykonawczą Prezydent Rzeczpospolitej Polskiej i Rada Ministrów, a władzę sądowniczą sądy i trybunały"5. Zasada ta, zwana zasadą podzia $\nmid u$ władzy (po szczegółowej analizie polskich uregulowań odnoszących się do każdej z tych władz oraz ich wzajemnych powiązań) charakteryzuje się tym, że władza sądownicza w Polsce powinna być niezależna, ,tylko sądy (i trybunały) mogą sprawować wymiar sprawiedliwości i w tym zakresie żaden inny organ państwowy nie może oddziaływać na ich rozstrzygnięcia". Natomiast w odniesieniu do władzy wykonawczej i ustawodawczej w naszym państwie ma zastosowanie

2 R. Małajny, Doktryna podziału władzy „Ojców Konstytucji” USA, Katowice 1985, s. 63-64.

3 W. Vázquez-Irizarry, Los poderes del Gobernador de Puerto Rico y el uso de ordenes ejecutivas, „Revista Jurídica Universidad de Puerto Rico”, vol. 76 (4), 2007, s. 985.

${ }^{4}$ L. Garlicki, Konstytucja Rzeczpospolitej Polskiej i inne akty normatywne. Wprowadzenie XII, Warszawa 2012.

5 Ibidem, s. 3-4. 
tzw. system hamulców i równowagi, który polega na tym, że obydwie te władze wzajemnie powinny się kontrolować ${ }^{6}$.

W przeciwieństwie do modelu ustrojowego w Portoryko władza wykonawcza w Polsce sprawowana jest przez Prezydenta i Radę Ministrów, a nie przez Gubernatora, co stanowi pierwszą dostrzegalną oraz charakterystyczną różnicę pomiędzy modelem polskim i portorykańskim (tzn. nie tylko terminologiczną, ale i ilościową przedstawicieli egzekutywy).

\section{Sposób sprawowania władzy wykonawczej}

\section{a) Portoryko}

Gubernatorowi portorykańskiemu w wykonywaniu władzy wykonawczej pomagają oraz towarzyszą sekretarze rzą dowi. Do prerogatyw Gubernatora należy ich powoływanie, które może nastąpić za uprzednią radą i zgodą Senatu Portorykańskiego (art. 4, pkt 5, KP). Izba ta, która wchodzi w skład Zgromadzenia Ustawodawczego (dwuizbowego), składa się co do zasady z dwudziestu siedmiu senatorów, którzy w niej zasiadają, oraz ponadto wykonują oni zgodnie z postanowieniami konstytucji inne wyznaczone funkcje (art. 3, pkt 2, KP i następne). Oznacza to, że Gubernator nie może arbitralnie ani swobodnie powoływać sekretarzy rządowych według swojego uznania. Zobowiązany jest on do tego, aby wcześniej zapoznać się z opinią Senatu Portorykańskiego odnoszącą się do kandydatów na sekretarzy rządowych oraz musi on od izby tej uzyskać przyzwolenie, aby oficjalne powołać określone osoby na sekretarzy rządowych. Natomiast wyjątek stanowić będzie procedura powołania S ekretarza S tanu, która następuje dodatkowo za uprzednią radą i zgodą Izby Reprezentantów (art. 4, pkt $5 \mathrm{KP}$ ). Należy tutaj zauważyć, że jest to druga z izb, która razem z Senatem tworzą w Portoryko Zgromadzenie Ustawodawcze. Na marginesie można dodać, że w izbie tej co do zasady zasiada pięćdziesięciu jeden przedstawicieli, którzy zostali wcześniej wybrani w przeprowadzonych wyborach (art. 3, pkt 2 KP). Tymczasem w odniesieniu do władzy wykonawczej należy podkreślić to, że wszyscy sekretarze rządowi tworzą wspólnie organ doradczy Gubernatora Portorykańskiego, czyli tzw. Ra dę S ekretarzy (art. 4, pkt 5 KP).

W Portoryko funkcjonują Rządowe Departamenty, tzw. wykonawcze, których istnienie jestzagwarantowane przez Konstytucje. Można wymienić tutaj dla przykładu: Departament Stanu, Departament Edukacji, czy Departament Sprawiedliwości. Ponadto Zgromadzenie Ustawodawcze, czyli Izba Reprezentantów oraz Senat portorykański, może tworzyć inne Rządowe Departamenty, które expressis verbis nie zostały wymienione w Konstytucji. Dodatkowo również do jego kompetencji należy reorganizacja oraz łączenie Departamentów Rządowych i określenie ich zadań, którymi mają się one zajmować. W tym ostatnim przypadku w szczególności chodzić

\footnotetext{
${ }^{6}$ Ibidem, Wprowadzenie, XIV-XV.
} 
będzie o zakres ich działalności. Ponadto do każdego Departamentu w Portoryko przyporządkowany jest odpowiedni Sekretarz Rządowy, który jest odpowiedzialny za jego funkcjonowanie (art. 4, pkt $6 \mathrm{KP}$ ). Wspominane w tym oraz w poprzednim akapicie kwestie zostały poruszone przez Williama Vázquez'a Irizarry, który również w tym przedmiocie odwołuje się w swoich cytowaniach bezpośrednio do postanowień tamtejszej Konstytucji z 1952 r. $^{7}$ Notabene można dodać, że aktualnie w Portoryko liczba Departamentów Rządowych wynosi co najmniej piętnaście ${ }^{8}$.

Ponadto w skład struktur władzy wykonawczej w Portoryko wchodzą: se kretariaty i biura, które bezpośrednio podlegają Gubernatorowi; a g e n cje wykonawcze, jednostki administracyjne orazinne instytucje public zne, które wykonują określone zadania9.

b) Polska

W Polsce władza wykonawcza sprawowana jest przez Prezydenta Rzeczpospolitej Polskiej oraz przez Radę Ministrów. W pierwszej kolejności przejdę do omówienia Rady Ministrów, a w następnej części artykułu porównam w wybranych aspektach Gubernatora Portorykańskiego oraz Prezydenta Rzeczpospolitej Polskiej.

Zgodnie z postanowieniami Konstytucji „Rada Ministrów składa się z Prezesa Rady Ministrów i ministrów"10. Ponadto istnieje dodatkowa możliwość rozszerzenia składu osobowego Rady Ministrów o wiceprezesów Rady Ministrów oraz otzw. ministrów bez teki ${ }^{11}$.

Proces powołania Rady Ministrów w Polsce składa się z kilku następujących po sobie różnych etapów, które w końcowym efekcie, w przypadku ich niepowodzenia, skutkować mogą skróceniem kadencji Sejmu i przeprowadzeniem ponownych wyborów. W skrócie Prezydent Rzeczpospolitej Polskiej powołuje Prezesa Rady Ministrów oraz członków Rady Ministrów. Następnie Sejm przystępuje do udzielenia tejże Radzie Ministrów wotum zaufania. Natomiast w przypadku kiedy nie zostanie ono udzielone, Sejm sam przedstawia własnego kandydata na premiera oraz proponowany przez niego skład Rady Ministrów, po czym przystępuje do głosowania. Tymczasem, jeśli kolejny raz nie zostanie ustanowiona Rada Ministrów, to ponownie „głowa państwa” ma możliwość powołania członków Rady Ministrów. W tej ostatniej sytuacji, jeżeli ponownie nie zostanie im udzielone wotum zaufania, to Prezydent rozwiązuje Sejm i zarządza wcześniejsze wybory parlamentarne ${ }^{12}$.

7 W. Vázquez-Irizarry, op. cit., s. 986.

$8 \mathrm{http} / /$ www2.pr.gov/directorios/pages/directoriodeagencias.aspx (dostęp: 01.09.2016).

9 http://www.gobierno.pr/NR/rdonlyres/37B3F21A-B714-4B9C-B966-96E6BCD499DB/0/ Organigrama.pdf (dostęp: 1.09.2016).

10 L. Garlicki, op. cit., s. 34.

11 Ibidem, Wprowadzenie, XXV.

12 Ibidem, s. 36. 
Rada Ministrów w Polsce odgrywa bardzo ważną rolę w strukturach państwowej władzy wykonawczej, a w jej hierarchii organizacyjnej oraz kierowniczej, znajduje się ona na najwyższym ich szczeblu. Natomiast sposób wykonywania tej władzy na poziomie centralnym realizowany jest w Polsce poprzez ministerstwa i urzędy centralne oraz przez samodzielne agencje. Tymczasem na poziomie lokalnym władzę rządową reprezentuje wojewoda wraz z podlegającym $\mathrm{mu}$ aparatem administracyjnym (w związku tym, że jest on przedstawicielem Rady Ministrów na obszarze każdego województwa) ${ }^{13}$. Aktualnie w Polsce mamy co najmniej dziewiętnaście ministerstw, których pracami kierują poszczególni ministrowie, będący również członkami Rady Ministrów. Dla przykładu, można wymienić następujące ministerstwa: Ministerstwo Rozwoju, Ministerstwo Cyfryzacji, Ministerstwo Sprawiedliwości, Ministerstwo Spraw Zagranicznych ${ }^{14}$.

Konstytucja przyznaje Radzie Ministrów ogólne uprawnienie do kierowania wewnętrzną oraz zewnętrzną polityką w naszym państwie. Wyjątkiem od powyższej zasady są inne sprawy czy kompetencje, które Konstytucja albo ustawa zastrzega na rzecz pozostałych organów państwowych, bądź powierza je do wykonania na szczeblu samorządowym. Dodatkowo w ustawie zasadniczej z 1997 r. (art. 146) wymienione zostały expressis verbis obowiązki Rady Ministrów, a ściślej ujmując to, co należeć powinno do zakresu jej działalności oraz zadań. Można wymienić tutaj kilka przykładów: „kieruje administracją rządową, kieruje wykonaniem budżetu państwa, zapewnia wykonanie ustaw, zapewnia wewnętrze i zewnętrzne bezpieczeństwo państwa oraz porządku publicznego"15.

W literaturze podkreśla się, że Prezes Rady Ministrów wykonuje następujące funkcje: „reprezentuje Radę Ministrów” oraz „kieruje jej pracami”, ma możliwość „wydawania rozporządzeń" na podstawie wyraźnego upoważnienia ustawowego, „Zapewnia wykonywanie polityki Rady Ministrów i określa sposoby jej wykonywania”, „koordynuje i kontroluje pracę członków Rady Ministrów”, „sprawuje nadzór nad samorządem terytorialnym” oraz ,jest zwierzchnikiem służbowym pracowników administracji rządowej i korpusu służby cywilnej”. Ponadto Prezes Rady Ministrów posiada również inne uprawnienia, takie jak np. o charakterze kreacyjnym, które, innymi słowy, dotyczą tworzenia własnych organów pomocniczych, jak i tych dla Rady Ministrów - na jej wniosek ${ }^{16}$.

W Polsce Konstytucja dopuszcza występowanie dwóch kategorii ministrów, którzy wchodzą w skład Rady Ministrów. Są to tak zwani: ministrowi e resortowi i ministrowie bez teki. Pierwsza kategoria ministrów kieruje określonym działem administracji rządowej, a druga realizuje zadania wyznaczone im przez Prezesa Rady Ministrów. Na marginesie, to Rada Ministrów

\footnotetext{
13 Ibidem, Wprowadzenie, XXV i s. 35.

$14 \mathrm{https} / /$ www.premier.gov.pl/ludzie.html (dostęp: 1.09.2016).

15 L. Garlicki, op. cit., Wprowadzenie, XXVI i s. 34.

16 B. Banaszak, op. cit., s. 523-526.
} 
jest odpowiedzialna za tworzenie, znoszenie czy przekształcanie ministerstw w Polsce poprzez wydawanie w tym celu stosownych rozporządzeń. Każdy minister realizuje swoje kompetencje jednoosobowo, pomagają im w tym sekretarze stanu - po jednym na ministerstwo - oraz podsekretarze stanu, których liczba przypadająca na poszczególne ministerstwa nie jest w żaden sposób ograniczona. Są oni powoływani przez Prezesa Rady Ministrów, na wniosek odpowiedniego ministra. Należy dodać również, że ministrowie w Polsce: „kierują, nadzorują i kontrolują działalność podporządkowanych organów, urzędów i jednostek" ${ }^{17}$.

\section{Gubernator portorykański a Prezydent Rzeczypospolitej Polskiej}

a) wybory oraz kadencja

Zarówno Konstytucja Portoryko (art. 4, pkt 1 KP), jak i Konstytucja RP (art. 127) wymagają, aby wybory były zarówno powszechne oraz bezpośrednie. Oznacza to, że każdy uprawniony do wzięcia czynnego udziału w wyborach (Polak czy Portorykańczyk) może oddać bezpośrednio swój głos na jednego z kandydatów na Prezydenta lub na Gubernatora. Dodatkowo Konstytucja w Polsce wymaga, aby wybory były ró w ne oraz żeby odbywały się w g ł o s o waniu tajnym ${ }^{18}$. Ustanowiona w Konstytucji zasada równości rozpatrywana jest w literaturze $\mathrm{w}$ dwóch aspektach: $\mathrm{w}$ formalnym oraz w materialnym. Ten pierwszy oznacza, że „każda osoba, której przysługuje prawo wyborcze (podmiotowe), uczestniczy w wyborach na takich samych zasadach, jak inni wyborcy, a w szczególności dysponuje taką samą liczbą głosów w przypadku czynnego prawa wyborczego oraz ma równe z innymi szanse w ubieganiu się o urząd wybieralny czy mandat przedstawicielski”. W znaczeniu materialnym każdy pojedynczy oddany głos ma tzw. „równą siłę”, czyli że odpowiada również jednemu ważnie oddanemu głosowi w wyborach oraz ma takie samo znaczenie, jak każdy inny $\mathrm{g} \nmid \mathrm{s}^{19}$.

Zarówno w Konstytucji Portorykańskiej, jaki i w Konstytucji RP ustanowiono identyczny cenzus wieku w biernym prawie wyborczym dla przedstawicieli egzekutywy (Gubernator, Prezydent), który w obu tych państwach wynosi trzydzieści pięć lat. Zgodnie z powyższym każdy z kandydatów na Prezydenta w Polsce, czy na Gubernatora w Portoryko, musi w dniu przeprowadzanych wyborów ukończyć trzydziesty piąty rok życia. $Z$ drugiej strony nie jest dopuszczalne ani nie zostały przewidziane wyjątki, aby osoba poniżej tej granicy wieku mogła w którymkolwiek z tych państw zostać Gubernatorem czy Prezydentem (art. 4, pkt 3

\footnotetext{
17 Ibidem, s. 526-527.

18 L. Garlicki, op. cit., s. 28-29.

19 B. Banaszak, op. cit., s. 275-276.
} 
$\mathrm{KP})^{20}$. Natomiast w Portoryko i w Polsce w sposób odmienny uregulowano cenzus obywatelstwa, co w sposób pochodny wynika $\mathrm{z}$ ich odrębności oraz różnicy terytorialnej, kulturowej, politycznej (w przypadku Portoryko: powiązanej ze Stanami Zjednoczonymi Ameryki) itd. Przekłada się to następnie na autonomię w decydowaniu - ustrojowym - o tym, kto może zajmować najważniejsze stanowiska publiczne w państwie. W tym miejscu należy również dodać, że pomimo przynależności Polski do Unii Europejskiej od każdego kandydata na urząd Prezydenta wymaga się wyłącznie posiadania naszego obywatelstwa, tzn. polskiego (jako tzw. warunek sine qua non), co innymi słowy w obecnych czasach oznacza, że musi się on legitymować co najmniej wskazanym obywatelstwem. Zostało to expressis verbis sformułowane w postanowieniach Konstytucji, przez co nawet samo posiadanie obywatelstwa innego kraju Unii Europejskiej nie zmienia tego faktu ani nie upoważnia nikogo formalnie per se do ubiegania się w Polsce o urząd Prezydenta ${ }^{21}$. Natomiast kwestie te inaczej zostały uregulowane w Portoryko, które politycznie stowarzyszone jest ze Stanami Zjednoczonymi Ameryki. W związku z tym od kandydata na Gubernatora Portoryko wymagane jest obywatelstwo amerykańskie, a oprócz tego cenzus obywatelstwa został dodatkowo „obostrzony”: tzn. w tym przypadku osoba taka musi je posiadać przed wyznaczonymi wyborami od co najmniej pięciu lat. Ponadto w tym samym czasie obowiązana jest ona zamieszkiwać w dobrej wierze terytorium Portoryko przez kolejno następujących po sobie pięć lat (art. 4, pkt. $3 \mathrm{KP}$ ). W tym miejscu można pokusić się o stwierdzenie, że tego typu wymogów na próżno można szukać w polskiej ustawie zasadniczej, ponieważ w tym przedmiocie (wymogów) zawiera ona krótkie odesłanie do postanowień, uregulowań dotyczących korzystania przez kandydata na Prezydenta RP z pełni praw wyborczych do Sejmu (art. 127 ust. 3) ${ }^{22}$.

Kadencja - tzn. okres faktycznego wykonywania obowiązków oraz pełnienia funkcji przez Gubernatora w Portoryko oraz przez Prezydenta w Polsce jest zupełnie inny. W tym kontekście należy dodać, że odmienny jest również moment objęcia przez nich w ła d zy, a innymi słowy jej początek, od którego dopiero zaczyna być liczona ich kadencja. W Portoryko kadencja Gubernatora wynosi cztery lata i rozpoczyna się tego samego dnia kalendarzowego, tzn. od drugiego stycznia. Zgodnie z postanowieniami Konstytucji z 1952 r. dzień ten powinien być poprzedzony wcześniejszymi wyborami na Gubernatora i dotyczy on już co do zasady następnego roku kalendarzowego (powyborczego), który przypada zaraz po wyborach (art. 4, pkt 2 KP). Natomiast kadencja Prezydenta w Polsce wynosi pięć lat i jest liczona od dnia, w którym objął on swój urząd. W tym kontekście i w odróżnieniu od Portoryko nie ma tutaj ściśle określonej daty ani sprecyzowanego roku kalendarzowego. Ponadto, zgodnie z Konstytucją RP, moment

\footnotetext{
20 L. Garlicki, op. cit., s. 28.

21 Ibidem.

22 Ibidem, s. 28-29
} 
objęcia urzędu Prezydenta w Polsce zaczyna się po złożeniu przez niego przysięgi przed Zgromadzeniem Narodowym ${ }^{23}$. Z drugiej jednak strony w Portoryko ustępujący Gubernator wykonuje wszelkie przewidziane obowiązki oraz funkcje, dopóki jego następca nie zostanie wybrany w wyborach oraz jeśli nie będzie on gotów do objęcia władzy (co stanowi wyjątek od przedstawionych wcześniej postanowień konstytucyjnych). Oprócz tego, zgodnie z Konstytucją RP, Prezydentem można być przez dwie kadencje, co oznacza, że jest dopuszczalna jedna reelekcja na ten urząd. W Portoryko z kolei Konstytucja w tym zakresie „milczy”, tzn. brak jest tego typu uregulowań, do których można byłoby się — w tym kontekście odnieść czy odwołać.

b) Uprawnienia i obowiązki

W pewnym zakresie część prerogatyw Gubernatora Portoryko oraz Prezydenta Rzeczpospolitej Polskiej została podobnie uregulowana w obu Konstytucjach. Niektóre z przysługujących im uprawnień pokrywają się ze sobą, a inne w ogóle nie występują bądź odpowiadają kompetencjom Rady Ministrów w Polsce. W tym ostatnim przypadku należy odnieść się do tego, że Gubernator jest odpowiedzialny za wykonywanie ustaw na terytorium Portoryko. Zwołać on może w określonych okolicznościach nadzwyczajne posiedzenia Zgromadzenia Ustawodawczego w Portoryko czy Senatu. Prezydent w Polsce w odniesieniu do żadnej z izb parlamentu takich kompetencji (uprawnień) nie posiada. Co najwyżej ma on możliwość zwołania Rady Gabinetowej w Polsce, kiedy ze względu na szczególną wagę sprawy jest to uzasadnione ${ }^{24}$. Ponadto Gubernator Portoryko ma możliwość powoływania funkcjonariuszy publicznych — zgodnie z postanowieniami zawartymi w Konstytucji oraz poszczególnych ustawach. Konstytucja RP w tym zakresie jest bardziej szczegółowa i wymienia dokładnie wśród prerogatyw Prezydenta, jakie osoby mogą zostać powołane przez niego na ważne funkcje oraz stanowiska państwowe. Dla przykładu można wymienić tutaj: powoływanie Prezesa Rady Ministrów, powoływanie członków Rady Polityki Pieniężnej, powoływanie członków Krajowej Rady Radiofonii i Telewizji ${ }^{25}$. W literaturze podkreśla się, że również Premier w Polsce „ma ponadto kompetencje do powoływania [...] wyższych urzędników państwowych [...] kierowników państwowych jednostek organizacyjnych oraz piastunów centralnych organów administracji rządowej”"26. Gubernator w Portoryko dodatkowo jest Naczelnym Dowódcą Gwardii Narodowej Portoryko (art. 4, pkt 4 KP). Przybliżonego odpowiednika o tego typu treści można się doszukiwać w polskiej konstytucji, w artykule 134, który najwyższe zwierzchnictwo nad siłami zbrojnymi powierza Prezydentowi. Oprócz tego należy przy tym wspomnieć, że również Prezydent RP mianuje Naczelnego Dowódcę Sił Zbrojnych

\footnotetext{
23 Ibidem, s. 29-30.

24 B. Banaszak, op. cit., s. 506-507.

25 L. Garlicki, op. cit., s. 33

26 B. Banaszak, op. cit., s. 525-526.
} 
na czas trwania wojny ${ }^{27}$. Ponadto, zgodnie z Konstytucją portorykańską, w trzech określonych przypadkach Gubernator może - w szczególności — skorzystać z Gwardii Narodowej. Po pierwsze, kiedy wymagać tego będzie ochrona porządku publicznego w Portoryko, następnie w sytuacji zaistnienia rebelii na jej terytorium, a po trzecie w celu odparcia inwazji (art. 4, pkt 4 KP). Identycznie jak Prezydent w Polsce, Gubernator portorykański może również wprowadzić stan wojenny; uprawnienie to wynika bezpośrednio z postanowień Konstytucji (art. 4, pkt $4 \mathrm{KP}) .{ }^{28}$ Również obaj, mogą skorzystać z przysługującego im prawa łaski, $\mathrm{z}$ tą różnicą, że uregulowania w Konstytucji portorykańskiej udzielają uprawnień Gubernatorowi w znacznie szerszym zakresie oraz umożliwiają mu głębszą ingerencje w sądownictwo powszechne (w porównaniu do analogicznych prerogatyw przysługujących Prezydentowi RP). W tym miejscu należy wymienić takie uprawnienia Gubernatora, jak: zawieszenie wykonalności wyroków sądowych w sprawach karnych, zamiana orzeczonej kary na łagodniejszą, darowanie w całości bądź w części nałożonych kar finansowych. Ten ostatni przypadek odnosi się również w sposób odpowiedni do wszelkiego mienia, które uległoby konfiskacie (art. 4, pkt $4 \mathrm{KP})^{29}$. Kolejną prerogatywą Gubernatora w Portoryko jest aprobowanie bądź odrzucanie rezolucji Zgromadzenia Ustawodawczego oraz przyjętych przez obie izby (wchodzące w jego skład) projektów ustaw (art. 4, pkt 4 KP). Uprawnienie to jest podobne do występującego w Polsce prawa weta, z którego może skorzystać Prezydent ${ }^{30}$. Zgodnie z Konstytucją portorykańską Gubernator ma obowiązek przedstawić Zgromadzeniu Ustawodawczemu informacje dotyczące „sytuacji w państwie” wraz ze stanem budżetu oraz planowane wydatki na kolejny „rok budżetowy” (art. 4, pkt $4 \mathrm{KP}$ ). W Polsce zupełnie inaczej to wygląda, ponieważ Prezydent ma prawo zwrócić się z orędziem „do Sejmu, do Senatu lub do Zgromadzenia Narodowego", które ma na celu wyłącznie wysłuchanie go, a treść tego wystąpienia nie może być poddana późniejszej dyskusji. Ponadto nie powoduje ono żadnych skutków prawnych w odniesieniu do izby czy izb, do których zostało skierowane. Jego treść, w przeciwieństwie do modelu występującego w Portoryko, jest otwarta i to, jakie kwestie w nim Prezydent przedstawi, czy na jakie problemy zwróci uwagę, zależy wyłącznie od niego ${ }^{31}$. W literaturze podkreśla się że, to „Rada Ministrów odpowiada za wykonywanie budżetu przed Sejmem, który udziela jej absolutorium. [...] do zakresu jej kompetencji należy uchwalanie [...] sprawozdania z wykonania budżetu. Powinna je wraz z informacją o stanie zadłużenia państwa przedstawić Sejmowi w ciągu 5 miesięcy od zakończenia roku

\footnotetext{
27 L. Garlicki, op. cit., s. 31.

28 Ibidem, s. 52.

29 Ibidem, s. 32.

30 Ibidem, s. 26-27; zob. więcej B. Banaszak, op. cit., s. 153-160.

31 B. Banaszak, op. cit., str. 503-504.
} 
budżetowego"32. W tym sprawozdaniu Rady Ministrów można się doszukać w pewnej części informacji, które Gubernator w Portoryko przedstawia Zgromadzeniu Ustawodawczemu. Z oczywistych względów, które wynikają z odrębności politycznych oraz z różnic ustrojowych, część uprawnień przysługujących Prezydentowi w Polsce nie przysługuje Gubernatorowi Portorykańskiemu. Należy tutaj wymienić między innymi: ratyfikowanie oraz wypowiadanie umów międzynarodowych czy mianowanie i odwoływanie pełnomocnych przedstawicieli w innych państwach i przy organizacjach międzynarodowych ${ }^{33}$.

c) Zdarzenia losowe oraz inne okoliczności przewidziane w Konstytucji

Konstytucja portorykańska przewiduje dwa typy zdarzeń losowych oraz różnych okoliczności, które wpływają na wykonywanie obowiązków przez Gubernatora. Pierwsze całkowicie pozbawiają go dalszej możliwości wykonywania swoich funkcji. W szczególności należy do nich zaliczyć: śmierć, rezygnacje, odwołanie; oraz niezdolność całkowitą i trwałą — ta ostatnia z nich, moim zdaniem, w zależności od okoliczności może być w sposób różny interpretowana, przez co pozostawia dosyć otwarty katalog sytuacji do zastosowania (art. 4, pkt 7 KP). Odwołanie Gubernatora Portorykańskiego może nastąpić wyłącznie w okolicznościach, które zostały przewidziane w konstytucji. Dotyczy to następujących sytuacji, takich jak: „zdrada, przekupstwo”, popełnienie „,innych ciężkich przestępstw”, a nawet dopuszczenie się tych „drobnych”, które świadczyłyby o „demoralizacji”" Gubernatora (art. 4, pkt 10 oraz art. 3, pkt 21 KP). Po przeanalizowaniu uregulowań konstytucyjnych w Portoryko można dojść do wniosku, że katalog zdarzeń, na podstawie których istnieje możliwość odwołania Gubernatora, nie ma charakteru stałego i w zależności od woli ustawodawcy może on ulec zmianie. Co ciekawe, odwołać Gubernatora może tylko i wyłącznie Senat portorykański głosami trzech czwartych wszystkich zasiadających w nim senatorów. Natomiast samo wszczęcie procedury odwołania Gubernatora może być dokonane jedynie przez portorykańską Izbę Reprezentantów, która inicjuje ją, jeśli „za” opowiedzą się dwie trzecie wszystkich zasiadających w niej osób (art. 3, pkt $21 \mathrm{KP}$ ). Drugi typ zdarzeń losowych oraz innych okoliczności nie został ściśle zdefiniowany w Konstytucji, ale postanowiono, że muszą one mieć charakter przemijający i tylko tymczasowo mogą one uniemożliwiać Gubernatorowi wykonywanie obowiązków. W obu przypadkach Gubernatora zastępuje Sekretarz Stanu, a jeśli on również nie może, to jego obowiązki sprawuje jeden z sekretarzy rządowych — określony uprzednio przez ustawę (art. 4, pkt 8 KP).

W Polsce, ,zdarzenia losowe” oraz ,inne okoliczności” można podzielić w różny sposób, na przykład: o charakterze stałym albo o charakterze przemijającym, albo takie sytuacje, w których Prezydent jest w stanie zawiadomić Marszałka

\footnotetext{
32 Ibidem, s. 520.

33 L. Garlicki, op. cit., s. 30-31.
} 
Sejmu o niemożności sprawowania urzędu, bądź w ogóle nie jest w stanie tego zrobić. W Konstytucji expressis verbis wymienia się takie przyczyny, jak: „śmierć, zrzeczenie się urzędu, stwierdzenie nieważności wyboru, niezdolność ze względu na stan zdrowia”, czy „orzeczenie Trybunału Stanu”, które skutkują tym, że tymczasowo Marszałek Sejmu wykonuje obowiązki Prezydenta - aż do czasu wyboru nowego. Bez względu na charakter przyczyny, która mogłaby zaistnieć i uniemożliwić Prezydentowi w Polsce wykonywanie funkcji, to - co do zasady - Marszałek Sejmu powinien go zastąpić, a jeśli on nie jest w stanie tego zrobić, to Marszałek Senatu ${ }^{34}$. W nawiązaniu do orzeczenia Trybunału Stanu będziemy mieli tutaj do czynienia z „odpowiedzialnością władzy”, czyli „mechanizmem instytucjonalnym, w ramach którego ktoś może zostać pociągnięty do odpowiedzialności" ${ }^{35}$ za naruszenie postanowień konstytucji oraz ustaw ${ }^{36}$.

\section{Podsumowanie}

Sposób sprawowania władza wykonawczej w Portoryko i w Polsce jest s w o isty dla każdego z nich. Innymi słowy, można posłużyć się stwierdzeniem, że pomimo pewnych cech wspólnych, różnią się one od siebie, a w szczególności można to lepiej zobrazować, gdy weźmiemy pod uwagę i przyjmiemy za kryterium rozstrzygające kilka wybranych aspektów. Po pierwsze, w Polsce władza wykonawcza jest sprawowania i podzielona pomiędzy Prezydenta a Radę Ministrów. W Portoryko sprawuje ją Gubernator, któremu pomagają Sekretarze Rządowi, tworzący Radę Sekretarzy. Po drugie, część z prerogatyw Prezydenta w Polsce w ogóle nie została zawarta ani nie jest przewidziana w Konstytucji portorykańskiej w odniesieniu do Gubernatora. Po trzecie, w Portoryko istnieją departamenty rządowe, które nie mają swoich odpowiedników wśród ministerstw w Polsce. Należy tutaj dla przykładu wymienić: Departament Spraw Konsumenckich ${ }^{37}$, Departament ds. Rodziny ${ }^{38}$. Po czwarte, kadencja Prezydenta w Polsce jest o rok dłuższa niż Gubernatora w Portoryko. Ponadto w Konstytucji RP nie ma ściśle wyznaczonego dnia kalendarzowego, w którym miałaby się ona rozpocząć.

\section{Bibliografia}

Banaszak B., Prawo konstytucyjne, Warszawa 2012.

Deryng A., Prawo konstytucyjne, Warszawa 2014.

Estructura del Estado Libre Asociado de Puerto Rico, http://www.gobierno.pr/NR/ rdonlyres/37B3F21A-B714-4B9C-B966-96E6BCD499DB/0/Organigrama.pdf.

34 Ibidem, s. 30.

35 B. Nowotarski, Kryzys zasady przedstawicielstwa a odpowiedzialność władzy w demokracji. Próba konceptualizacji, „Przegląd Sejmowy” 2014, nr 1 (120), s. 16.

36 A. Deryng, Prawo konstytucyjne, Warszawa 2014, s. 136

$37 \mathrm{http}: / /$ www2.pr.gov/Directorios/Pages/InfoAgencia.aspx?PRIFA=069 (dostęp: 1.09.2016).

$38 \mathrm{http} / / /$ www2.pr.gov/Directorios/Pages/InfoAgencia.aspx?PRIFA=122 (dostęp: 1.09.2016). 
Garlicki L., Konstytucja Rzeczpospolitej Polskiej i inne akty normatywne, Warszawa 2012.

Kancelaria Prezesa Rady Ministrów, https://www.premier.gov.pl/ludzie.html.

Konstytucja Portoryko, http://www2.pr.gov/SobrePuertoRico/Documents/elaConstitucion.pdf.

Małajny R., Doktryna podziału władzy „,Ojców Konstytucji” USA, Katowice 1985;

Nowotarski B., Kryzys zasady przedstawicielstwa a odpowiedzialność władzy w demokracji.

Próba konceptualizacji, „Przegląd Sejmowy”, vol. 120 (1), 2014.

Portal oficial del Estado Libre Asociado de Puerto Rico,

http://www2.pr.gov/directorios/pages/directoriodeagencias.aspx,

http://www2.pr.gov/Directorios/Pages/InfoAgencia.aspx?PRIFA=069,

http://www2.pr.gov/Directorios/Pages/InfoAgencia.aspx?PRIFA=122.

Vázquez-Irizarry W., Los poderes del Gobernador de Puerto Rico y el uso de ordenes ejecutivas, „Revista Jurídica Universidad de Puerto Rico”, vol. 76 (4), 2007.

\section{Executive power in Puerto Rico and in Poland - the comparison and analysis of some constitutional issues}

\section{Summary}

The way of performing the executive branch in Puerto Rico and in Poland is quite specific for each of them. Despite of many common features, both system models have differences. First of all, in Poland the executive branch is performed and divided between President and Council of Ministers. While in Puerto Rico, Governor is the one who performs the executive branch, and he has the assistance of Governmental Secretaries, establishing the Council of Secretaries. Second, the better part of prerogative of the President in Poland is not included at all, similarly is not covered in the Constitution of Puerto Rico in reference to the Governor. Third, in Puerto Rico, there are Governmental Departments, which do not have counterparts of the Ministries in Poland, for example Department of the Consumers' Affairs, Department on Family Matters. Fourth, the presidency in Poland is one year longer, than Governor in Puerto Rico. Also, in the Polish Constitution there is no designated day of calendar, in which the presidency has to start. 